\title{
A STRATEGIC APPROACH TO CLIMATE CHANGE IMPACTS AND ADAPTATION
}

Victor A. Sposito, Department of Primary Industries, Victoria
Correspondence to Victor A. Sposito: Victor.Sposito@dpi.vic.gov.au

This paper describes a strategic approach to examining potential climate change impacts on agricultural, forestry and regional/rural resources. It outlines a holistic framework that links impacts with adaptation actions that is consistent with new thoughts on preparing society for climate change. The assessment of the potential impacts is a logical extension of the land resource evaluation models described in the paper by Hossain et al. (2006) since it links land suitability analysis modelling, developed by Primary Industries Research Victoria (PIRVic), with climate change impacts modelling developed by the Commonwealth Scientific and Industry Research Organisation (CSIRO). The Framework is illustrated by its applications in two regions in the State of Victoria, AUSTRALIA. The project described in this paper is part of a joint national and state effort in Australia to improve the knowledge on, and tools to adapt to, climate change and climate variability.

\section{HUMAN-INDUCED CLIMATE CHANGE}

Many environmental aspects of Planet Earth are changing rapidly due to human, or anthropogenic, activity. The Millennium Ecosystem Assessment (MA), conducted under the auspices of the United Nations, concluded:

\begin{abstract}
"Over the past 50 years, humans have changed ecosystems more rapidly and extensively than in any comparable period of time in human history, largely to meet rapidly growing demands for food, fresh water, timber, fibre, and fuel. This transformation of the planet has contributed to substantial net gains in human well being and economic development, but not all regions and groups of people have benefited from this process - in fact, many have been harmed. Moreover, the full costs associated with these gains are only now becoming apparent (Reid, et al. 2005, 1).
\end{abstract}

Projections of population growth and economic development indicate that such global changes are expected to accelerate in the first decades of the $21^{\text {st }}$ century (Alcamo 2002; Steffen et al. 2004; Diamond 2005).

The Earth's climate has always varied. Planetary positions, the orientation of the Earth, solar emission, volcanic activity and asteroids have impacted on climate over thousands to millions of years. Such changes have driven biological evolution, colonisations and natural extinctions. These mechanisms will lead to further climate change ${ }^{1}$ in the future, but the probability of them producing sustained and substantial climatic change during this century is very low (Pearman 2005).

There is nevertheless a general consensus among scientists and decision-makers that the climate is substantially and inexorably changing. For instance, the Third Assessment Report of the Intergovernmental Panel on Climate Change (IPCC 2001a; IPCC 2001b) concluded that clear signs of climate change are currently detectable around the world. Human activities, including the 
burning of fossil fuels, land clearing and the development of more intensive agricultural systems, have led to an increase in the concentration of greenhouse gases $(\mathrm{GHG})^{2}$ in the Earth's atmosphere. This is resulting in an increased amount of heat trapped by the atmosphere leading, in turn, to a change in the Earth's climate known as the enhanced greenhouse effect. The prognosis is one of further climate change through this century with impacts in all natural and human systems.

Some of the key evidence about climate change and related aspects are the following:

- Since the beginning of the industrial revolution (about 1750), the atmospheric level of carbon dioxide $\left(\mathrm{CO}_{2}\right)$, the main greenhouse gas, has increased by about $32 \%$ (from about 280 parts per million - ppm, to $380 \mathrm{ppm}$, its highest level for at least 720,000 years), primarily due to the combustion of fossil fuels and land use changes (Flannery 2005). Approximately $40 \%$ of the historical emissions (over the last two centuries), and about $20 \%$ of current $\mathrm{CO}_{2}$ emissions (in the 1990s) originated from changes in land use and land management, primarily deforestation. Terrestrial ecosystems were a sink for about a third of the cumulative historical emissions and a third of total emissions in the 1990s (energy plus land use) (Reid et al. 2005).

- In Antarctica, the extent of sea ice was stable from 1840 to 1950 but has decreased sharply since, to such an extent that the northern boundary of the ice has shifted from $59.3^{\circ}$ latitude south to $60.8^{\circ}$ S. This corresponds to about $20 \%$ decrease in the extension of sea ice (Curran et al. 2003). The observed reduction in krill numbers in Antarctica matches closely the reduction of sea ice over time to indicate that climate change is a major threat to the Earth's most productive ocean, and to the animals that exist and feed there (e.g. marine mammals and birds). In the Artic (region surrounding the North Pole), since 1979, more than $20 \%$ of the polar ice cap has melted away (Flannery 2005).

- The observed sea level rise over the $20^{\text {th }}$ century has been 1 to $2 \mathrm{~cm}$ (Pittock 2003).

- Land cover changes since 1750 have increased the reflectivity to solar radiation (albedo) of the land surface, partially offsetting the warming effect of associated $\mathrm{CO}_{2}$ emissions (Reid et al. 2005).

- The Earth is absorbing more energy (an extra 0.85 watts per square metre) than is radiating to space. That is the amount of heat emitted by 2-3 miniature light globes (e.g. those used in Christmas trees). This energy balance is tiny compared with the 235 watts/sq metres received from the Sun, but over decades it will accumulate (Flannery 2005).

The stakes associated with projected changes in climate are high. Numerous Earth systems that sustain human societies are sensitive to climate and will be impacted by changes in climate. Impacts can be expected in ocean circulation; sea level; the water cycle; carbon and nutrient cycles; air quality; the productivity and structure of natural ecosystems; the productivity of agricultural, grazing, and timber lands; and the geographic distribution, behaviour, abundance, and survival of plant and animal species, including vectors and hosts of human disease. Climate change impacts will affect the prospects of sustainable development in different parts of the world and may further widen existing inequalities (IPCC 2001c, 21). 
Under enhanced greenhouse conditions, seasonal and other types of climate variability are important to climate impacts because they affect major regional anomalies of rainfall (and thus flood and drought occurrences), cloud cover, local sea-levels, ocean currents, and the incidence of cyclones and hurricanes. These climate extremes are often the most damaging for society (Collins et al. 2000; IAWG 2001; Pittock 2003).

\section{AUTONOMOUS AND PLANNED ADAPTATIONS: POLICY RESPONSES}

Although the stakes are high, the risks associated with climate change are less easily determined. These risks are a function of the probability and magnitude of impacts. In Figure 1, 'exposure' is the type and degree to which natural and human systems are exposed to climate changes. The systems affected by the changes can trigger "autonomous", or expected adaptations. Autonomous adaptations will shape the residual, or net, impacts of climate change. Policy responses to impacts already perceived or in anticipation of (potential) future impacts can take the form of "planned adaptations" to reduce adverse effects or enhance beneficial ones. Responses can also take the form of actions to mitigate climate change through greenhouse gas (GHG) emission reductions and enhancement of carbon sinks.

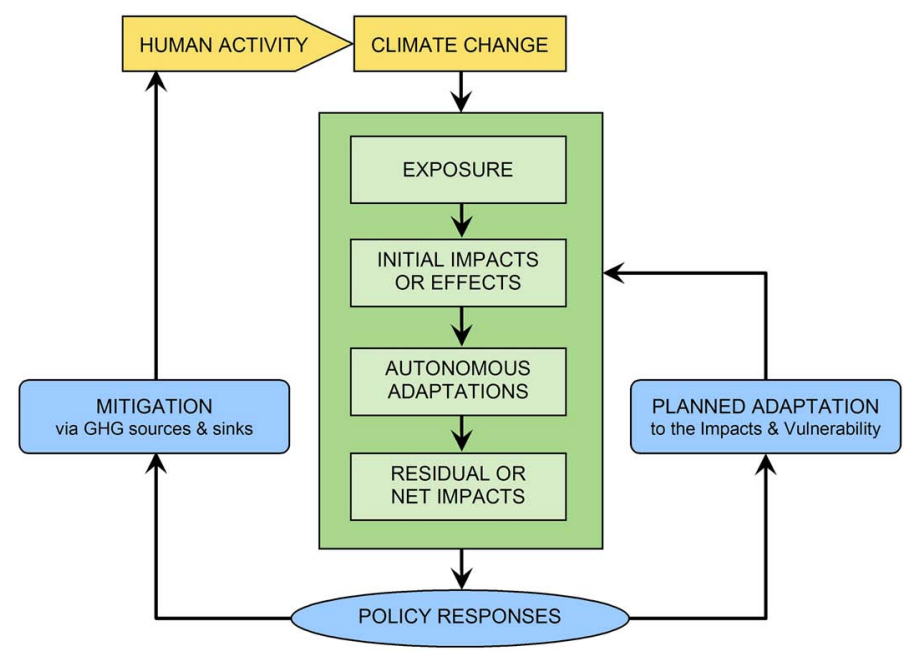

Figure 1 Policy Responses to Climate Change Source: adapted from IPCC 2001c, 22.

Climate change must however be considered in the context of other global changes and the stresses these impose on human society and regional/local ecosystems. Rapid demographic and social, economic, technological and political changes may contribute to increased pressure on water resources or agriculture production, or to increased exposure to extreme events such as cyclones. Other changes may serve, either, incidentally or by intent, to reduce vulnerability to climate change (Feenstra et al. 1998).

The adoption of the Kyoto Protocol by most countries of the World, under the terms of the United Nations Framework Convention on Climate Change (UNFCCC), is expected to reduce $\mathrm{CO}_{2}$ concentrations, future warming and sea-level rise relative to those resulting from uncontrolled 
emissions. There is, however, an increasing realisation among scientists and decision-makers that even if the targets of the Kyoto Protocol are achieved, other measures are urgently needed to reduce the adverse socio-economic and environmental effects of climate change, and to take advantage of any opportunity it presents. In other words, we must quickly put into place planned adaptations.

These will include, for example: (a) establishing habitat corridors to link areas of remnant vegetation to both expand habitats and facilitate movement of species in advance of the impacts of climate change, (b) designing and constructing stormwater infrastructure that has the capacity to carry increased water flow, or (c) ensuring that planning statutory schemes halt construction in areas likely to be affected by sea level rise (The State of Victoria 2002, 2004 and 2005).

\section{CLIMATE CHANGE IN VICTORIA}

\section{STRATEGIC OBJECTIVES}

The Australian (National) Government's report on "Climate Change Risk and Vulnerability" identified agriculture as the second highest national priority for further adaptation research and dissemination of information (Department of the Environment and Heritage 2005; see also Australian Greenhouse Office 1998). In the State of Victoria, the main policy documents of the State Government are the Victorian Greenhouse Strategy (The State of Victoria 2002) and its latest update (The State of Victoria 2005). Most recently, the State Government released "Our Environment Our Future - Sustainability Action Statement” (The State of Victoria 2006) which contains 16 strategic initiatives to put sustainability principles into action. In particular, Action 3 , includes several initiatives to make Victoria's agricultural systems resilient to climate change, and understand what climate change will mean for individual communities in regions so that they can better prepare.

Within this policy context, the purpose of the PIRVic project reported in this paper is twofold:

1. develop and apply a decision-analytic assessment and management framework for climate change impacts and adaptation in the Victorian agricultural (grains, horticulture, fruits, dairy) and forestry industries; and

2. assess which agricultural practices maximise Victorian agricultural and forestry industries' ability to adapt to climate change; and identify decision-making tools that enhance the industries' ability to adapt to climate change.

Application of the framework will determine the risks (problems and opportunities) associated with climate change in those key industries within Victorian regions, whilst the information drawn together through stakeholder consultation will enhance our knowledge and understanding of farmers and industries' ability to adapt to climate change. The information gathered throughout the project will underpin policy development in natural resource-based industries. ${ }^{3}$

\section{METHODOLOGY}

Figure 2 shows the climate change impacts, vulnerability and adaptation assessment/ management framework (hereafter the 'Framework'). ${ }^{4}$ It consists of eight main stages from 'problem formulation' to 'monitoring, evaluation and review'. A complementary 'Literature Review' (Box B), feeding into the main phases, is also shown in the Figure (see Sposito et al., 2006a). Project 


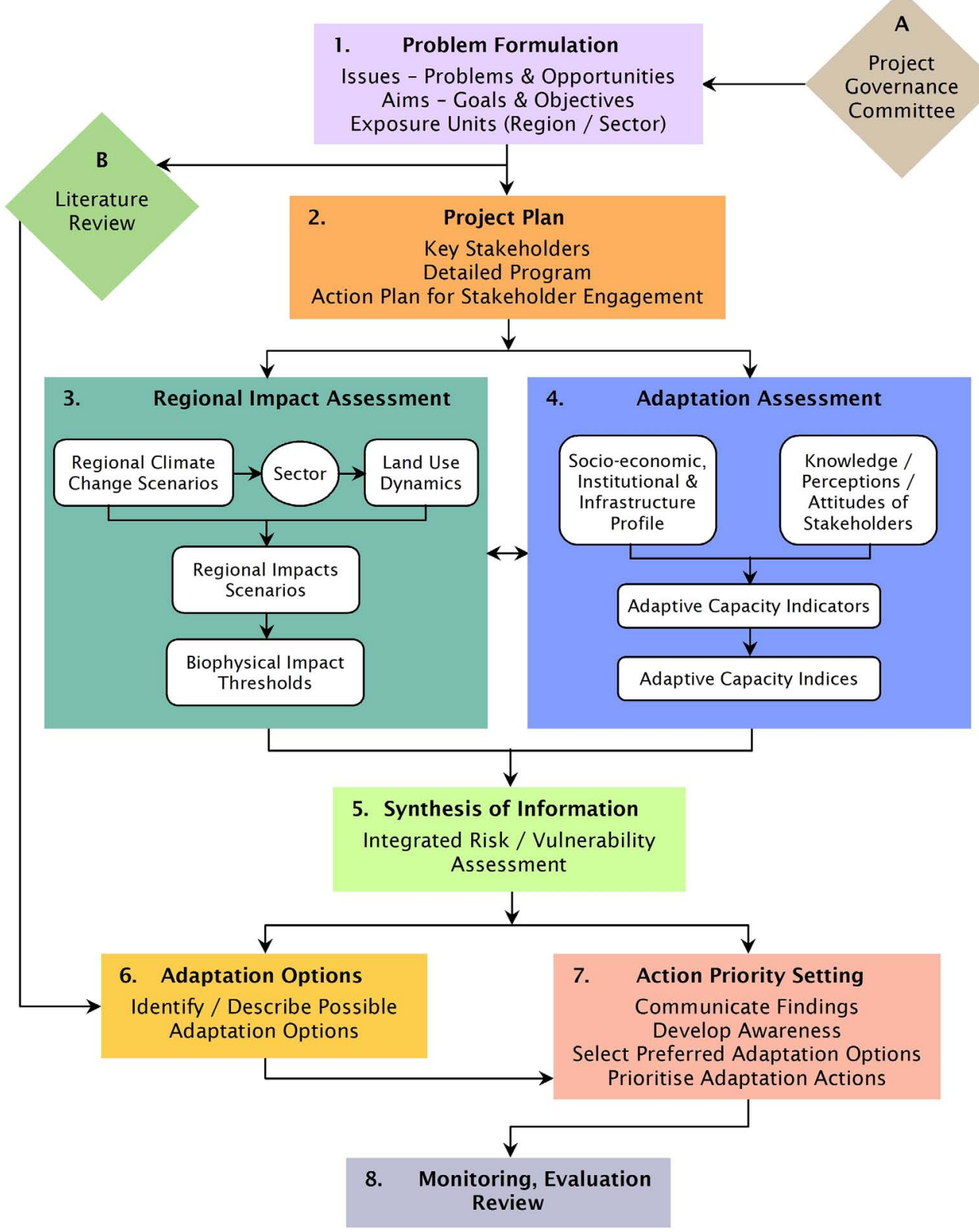

Figure 2 Main Activities in the Decision-Analytic Framework

development is guided by a Project Governance Committee, depicted in the Figure as Box A, with members representing key stakeholders. The Framework integrates long-term climate change projections (scenarios) with climate change variability (seasonal) forecasting (Box 3) that are undertaken in parallel with vulnerability and adaptive capacity assessment (Box 4). Since, climate 
change can be considered as an environmental risk, the Framework is based on a risk assessment approach (Standards Australia/Standards New Zealand 2004; Burgman 2005). This complete framework has some similarities with the UNDP Adaptation Policy Framework (United Nations Development Program 2001) and the UKCIP Risk Assessment Framework (Willows and Connell 2003); see also Jones 2000; Turner et al. 2003; and Centre for Integrated Regional Assessment, 2004.

The Framework is informed by Victorian Government's relevant policy statements/ initiatives on climate change, as well as the realisation of Sustainability/Sustainable Development (World Commission on the Environment and Development 1987; Beder 1996). Stakeholders are fundamental to, and participate throughout, the process; they include National, State and Local Governments; regional organisations (e.g. Catchment Management Authorities - CMAs); key agricultural/forestry industries; and Non-government Organisations (e.g. Landcare Groups) and the wider community. However, the main target audience of the project is decision-makers in the State Government of Victoria, CMAs, and the key agricultural/forestry industries.

Some activities must be undertaken in a sequential way (e.g. Phases 1 to 2; Phases 7 to 8 ), whilst others can be carried concurrently to be able to benefit from the respective analysis (e.g. Phases 3 and 4). The figure depicts the complete process to be undertaken from initial problem definition to implementation and monitoring. In its application to the key industries in various regions, the process can be stopped (in consultation with stakeholders) after the information generation stages outlined in Figure 2.

At present, the project is focusing in one region (North-Western Region-Map 1) in the State of Victoria, Australia, and in one key industry (grains - wheat and barley) within that region which is considered to be most at risk from climate change (see Sposito et al. 2005). In subsequent years, the project will progressively cover the whole of Victoria.

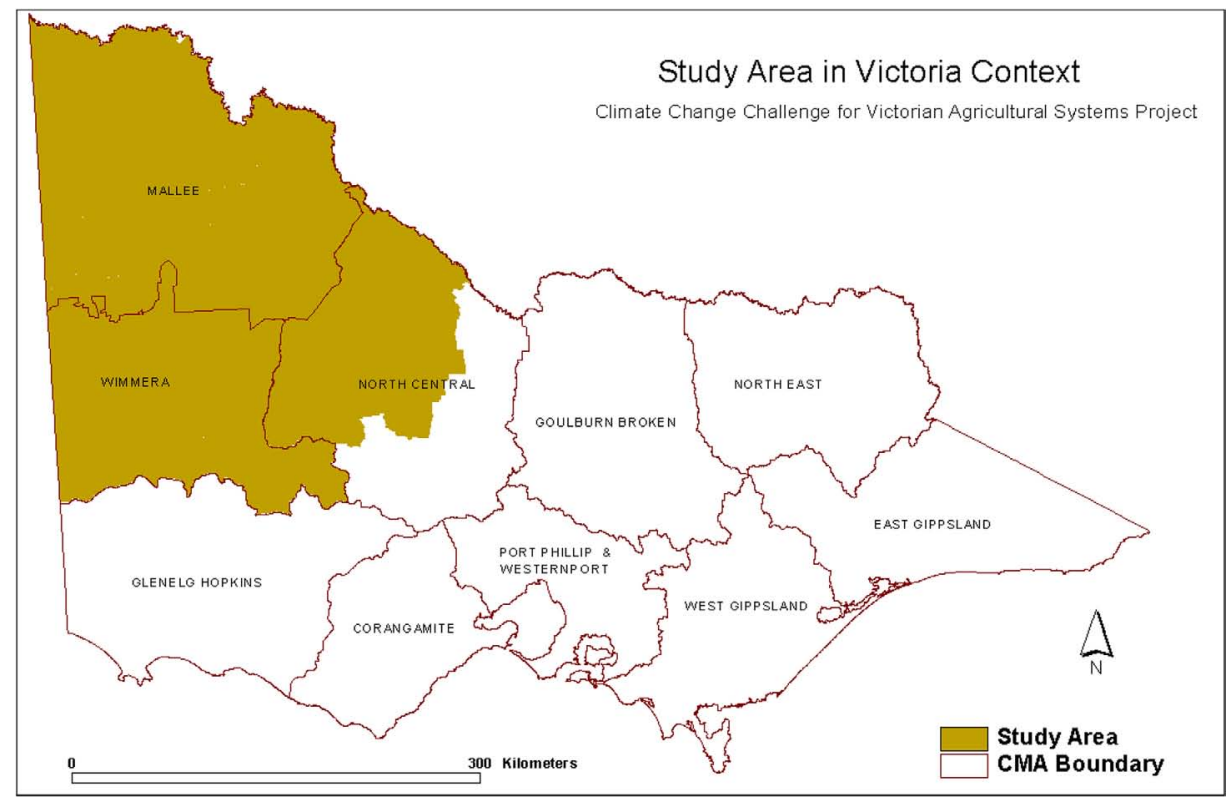

Map 1 North-Western and Goulburn Broken Regions of the State of Victoria, Australia 
This paper describes the initial research on the overall approach, undertaken in the GoulburnBroken Region of Victoria during 2002-04 (Sposito et al. 2004); and current work associated with Phase 3 of the framework in the North-Western Region of Victoria. Phase 4 of the framework is covered in Sietchiping (2006) in this special issue of Applied GIS.

\title{
PROJECTING FUTURE CLIMATE CHANGE
}

\section{PROJECTIONS AND SCENARIOS}

There can be considerable confusion regarding the various terms used to characterise future climate change, namely 'scenarios' and 'projections'.

\begin{abstract}
A scenario is a plausible description of some future state, with no statement of probability. It is used to enable people to explore the question 'What if such and such were to happen?' Scenarios are often used in literature to stretch the imagination, and increasingly in businesses and government to help to develop a range of strategies or contingency plans to cope with possible changes in business or other conditions. Scenarios are alternative pictures of how the future might develop... Projections are sets of future conditions, or consequences, based on explicit assumptions, such as scenarios (Pittock 2005, 47-48).
\end{abstract}

Even in the absence of estimated probabilities, scenarios are very useful in adaptation policy (that is, how to cope with unavoidable climate change) since they indicate what conditions natural and human systems might need to adapt to in the future. Scenarios help us to anticipate what sort of adaptations might be needed, and identify the need for increased resilience (capacity to bounce back) and adaptive capacity (capacity to adapt to change) in the system of concern.

\section{APPROACH TO REGIONAL PROJECTIONS AND IMPACTS}

To estimate the future climate impacts several assumptions are made and many models of the coupled climate/natural/human systems are used. These range from models of human society leading to GHG emissions (socio-economic models), through models of how much of the emitted GHG stay in the Earth's atmosphere (carbon cycle models), to their effects on global climate (climate models), through regional or local climatic changes (downscaling models), and finally to the impacts of climate change on natural and human systems (sectoral impact models) (IPCC 2001a; IPCC 1994, Jones 2000), ${ }^{5}$ Figure 3. This Figure also includes the main organisations where the models and projections have been, or are, developed and/or applied in the project.

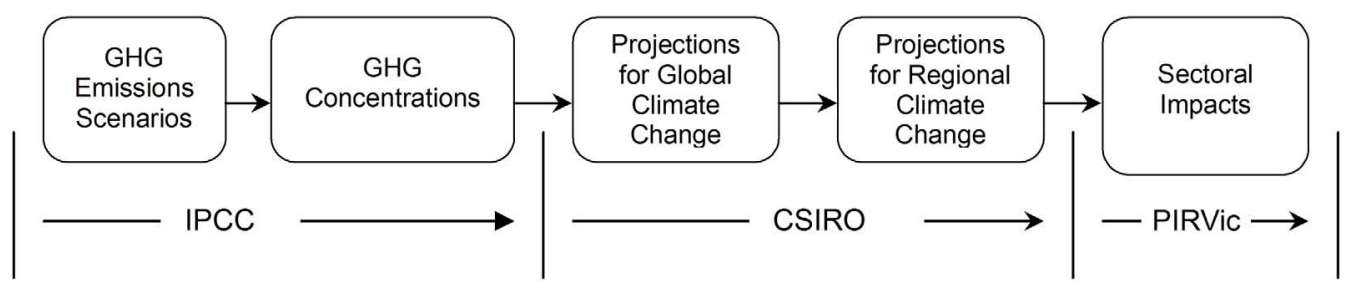

Figure 3 Chain of Models 


\section{THE IPCC GHG EMISSION SCENARIOS}

The departing point in the chain of reasoning is the GHG emission scenarios. These were developed by a panel of scientists with wide range consultation with, and reviewed by, experts and governments. They were reported in the Special Report on Emission Scenarios - SRES (Nakicenovic and Swart 2000).

An initial 40 SRES scenarios were based on four different 'storylines', or narratives, of internally consistent developments across various driving forces, and multiple modelling approaches leading to a total of 35 scenarios containing data on all gases required to force climate models - carbon dioxide $\left(\mathrm{CO}_{2}\right)$, methane $\left(\mathrm{CH}_{4}\right)$, nitrous oxide $\left(\mathrm{N}_{2} \mathrm{O}\right)$ and sulphur dioxide $\left(\mathrm{SO}_{2}\right)$. They are structured in four major 'families' labelled $A_{1}, A_{2}, B_{1}$ and $B_{2}$ and are organised along two axes; each family emphasises different social and economic future possibilities (scenarios). The scenarios do not include explicit policy options to reduce GHG, such as those as adopted under the UNFCCC (Parry and Carter 1998; Ruosteenoja et al. 2003). Six of the SRES scenarios for Carbon Dioxide $\left(\mathrm{CO}_{2}\right)$, representing the families of technology-population economy futures, are shown in Figure 4. For comparison purposes, the IPCC IS92 range of global warming in 2100 (which is based on earlier estimates) is also shown.

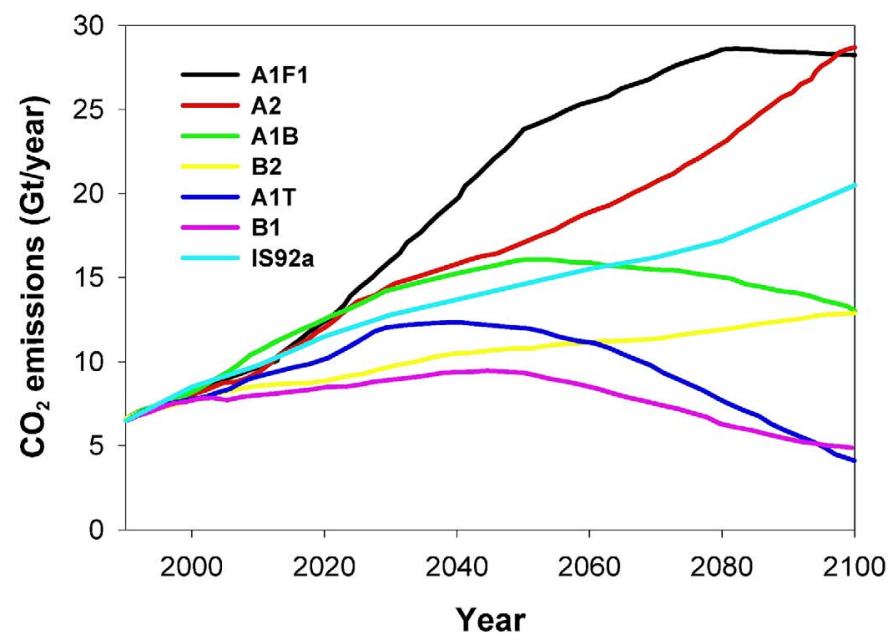

Figure 4 SRES Emission Scenarios for Carbon Dioxide Source: IPCC 2001a, Figure 22(a) of the Technical Summary.

\section{REGIONAL CLIMATE CHANGE PATTERNS}

Regional climate change patterns provide a spatial representation of the sensitivity of the regional atmospheric circulation under global climate change projections. Whetton et al. (2002) showed that atmosphere-ocean general circulation models (AGCMs) satisfactorily simulate observed patterns of temperature, precipitation and mean sea level pressure over south-eastern Australia. Consequently, ranges of change in average rainfall and temperature for Victoria were prepared based on: (a) the global warming projections in Figure 5 which provide information on the magnitude of the global climate response over time, and (b) the results of nine climate models. The ranges of change incorporate quantifiable uncertainties associated with the emission scenarios, 
the range of global responses of climate models, and model to model differences in the regional pattern of climate change.

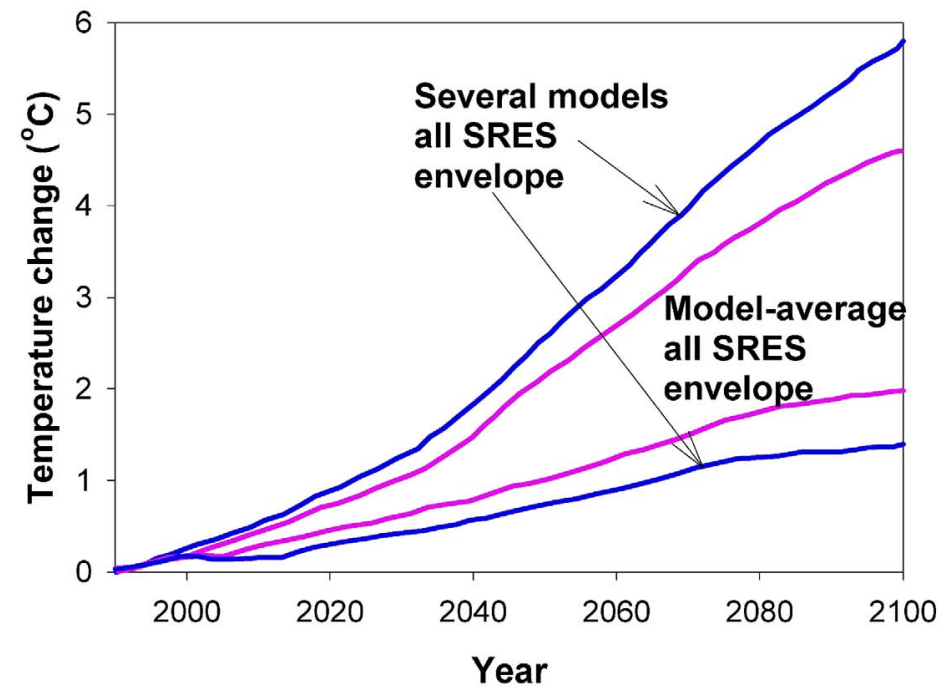

Figure 5 SRES Projects of Global Warming

The regional response is presented in terms of the local change of the key climatic variables of temperature and rainfall. Temperature is reported in degrees Celsius, while precipitation is presented in percentage per degree of global warming. This shows the changes that may be expected in the next few decades and the larger changes that may occur late in the century. It should be noted that they are changes in average climatic conditions, since the conditions of any individual year will continue to be strongly affected by natural climatic variability (as mentioned in the introduction) and cannot be predicted (CSIRO 2001).

\section{SECTORAL IMPACTS: LINKING LAND SUITABILITY MODELLING AND CLIMATE CHANGE IMPACTS MODELLING AT THE REGIONAL LEVEL}

\section{INTEGRATING MULTI-CRITERIA EVALUATION WITH GIS}

As discussed in the paper by Hossain et al. (2006) in this special issue of Applied GIS, determining the optimal biophysical use of the land resource is a complex process involving multiple decisions. For this purpose, PIRVic developed a Spatial Decision Support System (SDSS), which uses a Multiple Criteria Evaluation (MCE) method in a Geographic Information Systems (GIS) platform. MCE methods are well known tools for dealing with complex problems where a number of factors have to be considered. Specifically, MCE methods have been devised to investigate a number of alternatives (or choice possibilities) in light of multiple objectives (or criteria) and conflicting preferences (or priorities) (Voogd 1983; Nijkamp et al. 1990; Kenney and Raiffa 1993). 
The SDSS developed by PIRVic uses the Analytic Hierarchy Process (AHP), which is a MCE method that ranks factors in a hierarchy of importance (logic tree) through a pair-wise comparison (Saaty 1994; Schmold et al. 2001; Ramanathan 2001).

\begin{abstract}
AHP is a method of breaking down a complex unstructured situation into its components parts; arranging these parts, or variables, into an hierarchical order; assigning numerical values to subjective judgements based on the relative importance of each variable; and synthesising the judgment to determine which variable have the highest priority and should be acted upon to influence the outcome of the situation (Saaty, 1995, 5).
\end{abstract}

The integration of the AHP with GIS combines a robust decision support method with powerful mapping and visualisation capabilities, which, in turn, considerably facilitates the generation of land use suitability maps (Carver 1991; Jankowski 1995). A full description of the approach can be seen in the article by Hossain et al. (2006) in this special issue of Applied GIS.

\title{
VICTORIAN CLIMATE CHANGE MODELS
}

Each agricultural commodity has specific growth requirements that can be largely characterised through soil, climate and terrain aspects. Following a best-practice approach, the conditions for plant growth for each intrinsic (biophysical) factor are developed according to high productivity levels. With the participation of experts in agronomy, soil science, land use, climate and region$\mathrm{al} /$ local conditions, a hierarchy is constructed for a particular commodity and growth factors are detailed and ranked from the viewpoint of plant growth. The Land Suitability Analysis (LSA) modelling generates a composite map in which the area of concern (e.g. a region, a Local Government jurisdiction) is categorised in five major classes of 'very low', 'low', 'moderate', 'high' and 'restrictive' from a suitability viewpoint. PIRVic has developed over thirty different models to produce land suitability maps for vegetables, crops, fruits, floriculture, pastures, and forestry (plantations and agro-forestry).

During 2002-2004, PIRVic carried out the initial research on the impact of climate change on selected agricultural/forestry systems in the Gippsland Region (Cool Climate Grapes, Blue Gum, and pasture) and Goulburn Broken Region (Pome Fruit - pears and apples) (Hood et al. 2002; Sposito et al. 2004). The results of the modelling exercise to explore the impact of climate change on apples in the Goulburn Broken Region are shown in Maps 2-4. In all maps, areas with the highest suitability are illustrated in dark green whilst those with moderate suitability are shown in light green.

Map 2 shows land suitability for the production of apples in the Year 2000 ('baseline' year). Areas highly suitable for apples production are located to the north of the region on the riverine plains. Map 3 shows the land suitability in the Year 2050 under a moderate emissions scenario (B1). The contiguous area of high suitability for apples production has moved to the south, extending along the Goulburn Valley as far as the town of Nagambie; whilst areas in the north that were considered highly suitable in Year 2000 would become moderately suitable. The overall area of apple suitability would remain almost the same, and areas of low suitability would diminish in size only slightly. Map 4 illustrates the land suitability for apples in the Year 2050 under an extreme emissions scenario (A1F1). The area highly suitable is reduced in size and 
moves significantly to the central west part of the region. The area of high suitability identified in the Year 2000 is almost transformed into an area of moderately suitable. However, the area does not move significantly to the south when compared to the moderate scenario for 2050.

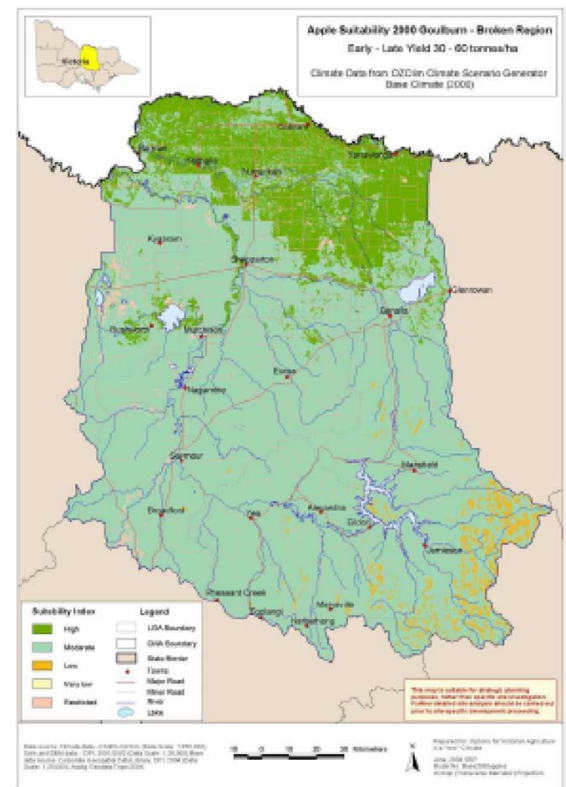

Map 2 Land Suitability for Apples - Baseline Year 2000

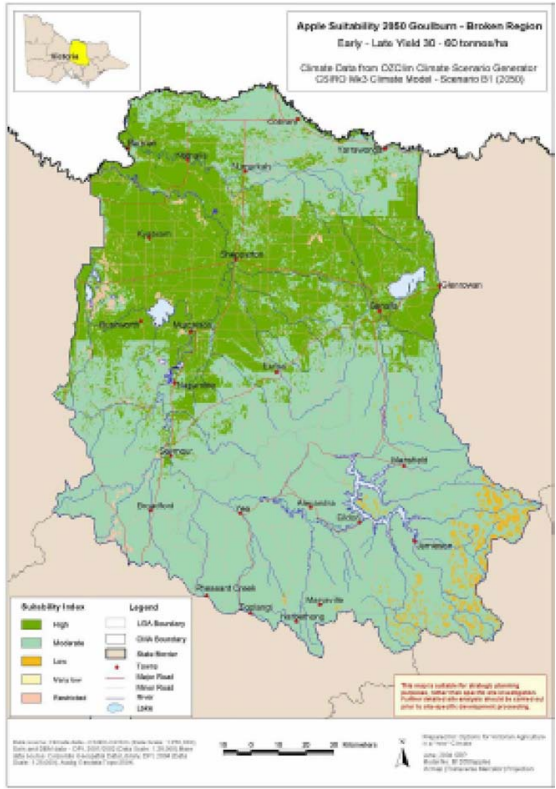

Map 3 Land Suitability for Apples - Moderate Emissions Scenario B1 2050 


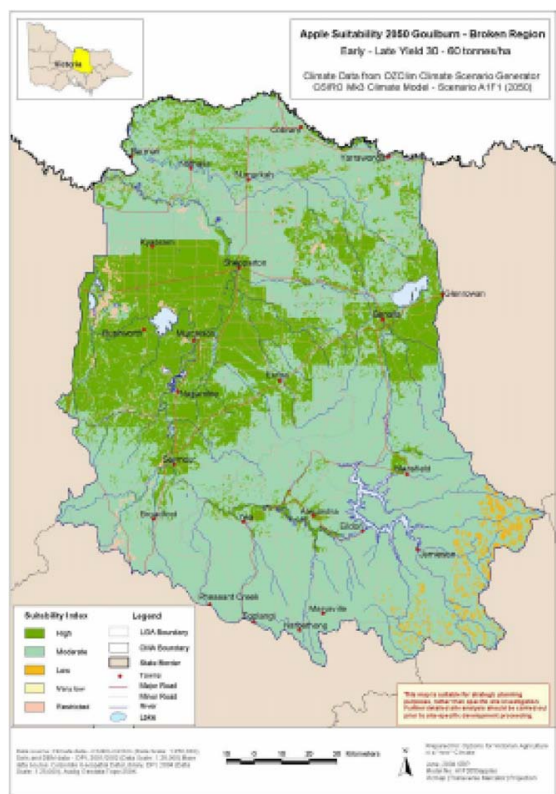

Map 4 Land Suitability for Apples - Extreme Emissions Scenario A1F1 2050

Source: Sposito et al. 2004

\section{INITIAL RESULTS IN THE NORTH-WESTERN REGION OF VICTORIA}

The model formulated to determine the biophysical factors for the growth of Winter Wheat in the North-Western Region of the State of Victoria is shown in Figure 6.

The results of the modelling exercise to explore the potential long-term biophysical impact of climate change on Winter Wheat in the North-Western Region of Victoria are shown in Maps 5-7. The year 2000 is taken as the 'baseline' year for comparison purposes. A moderate scenario (B1) and an extreme scenario (A1F1) (see Figure 4) have been illustrated to provide an indication of the potential range of impacts.

Maps 8 and 9 show the comparisons between the land suitability for the baseline climatic variables (Year 2000), and the moderate scenario (B1) and the extreme scenario (A1F1), respectively, for the year 2050. Each map also includes a table that gives an estimate of the areas of land suitability change. As in the case of Pome fruits - apples in the Goulburn Broken Region (Maps 2-4), there are significant changes in the land suitability for the production of winter wheat. For instance, the decreases in suitability (small plus moderate) varies from about $22 \%$ in the moderate scenario (B1) to about $27 \%$ in the extreme scenario (A1F1), whilst the increases in land suitability are very small (less the $0.11 \%$ ) in both scenarios. 


\section{WINTER WHEAT LAND SUITABILITY Inherent Factors AHP Model}
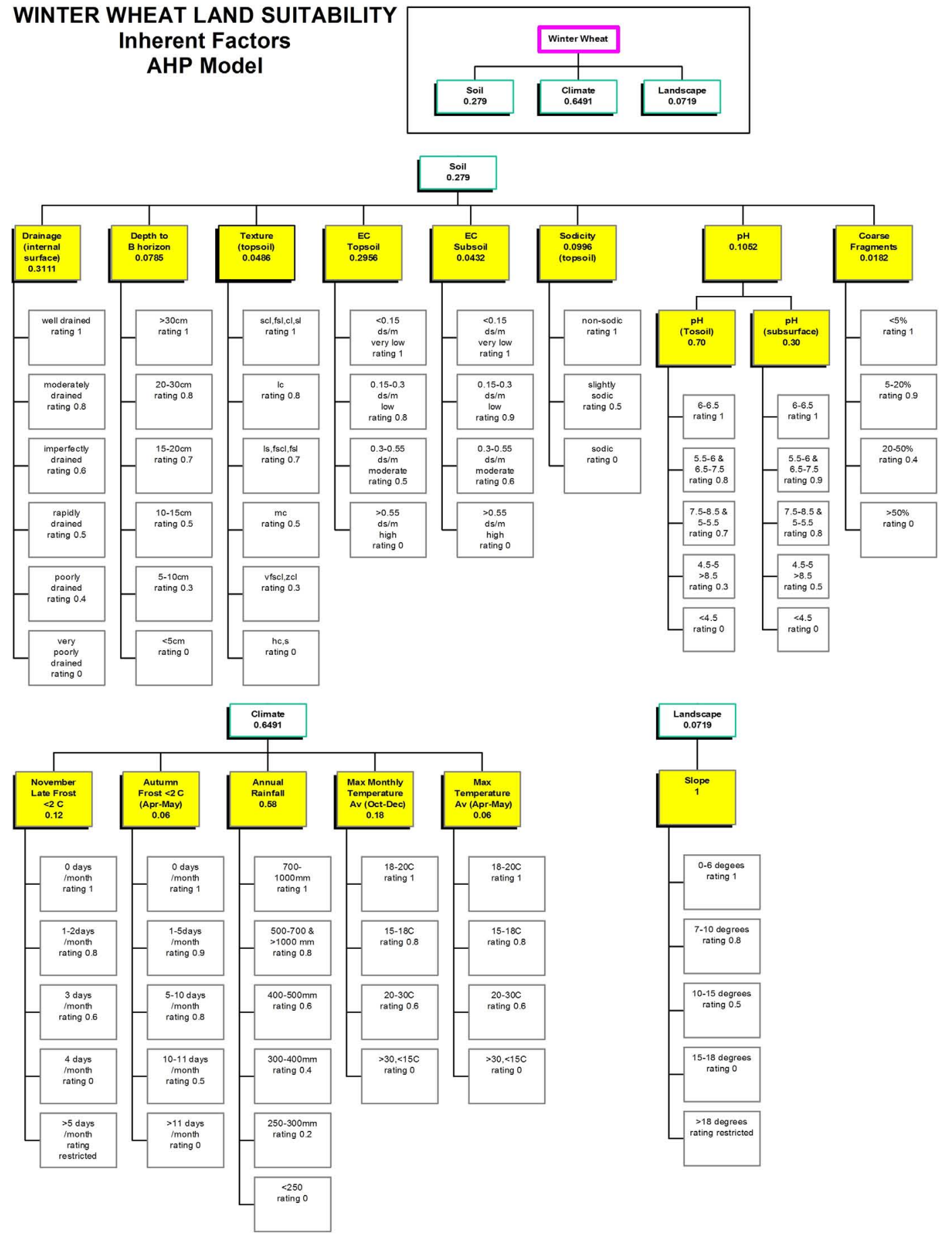

Figure 6 Winter Wheat - Model for Climate Change 


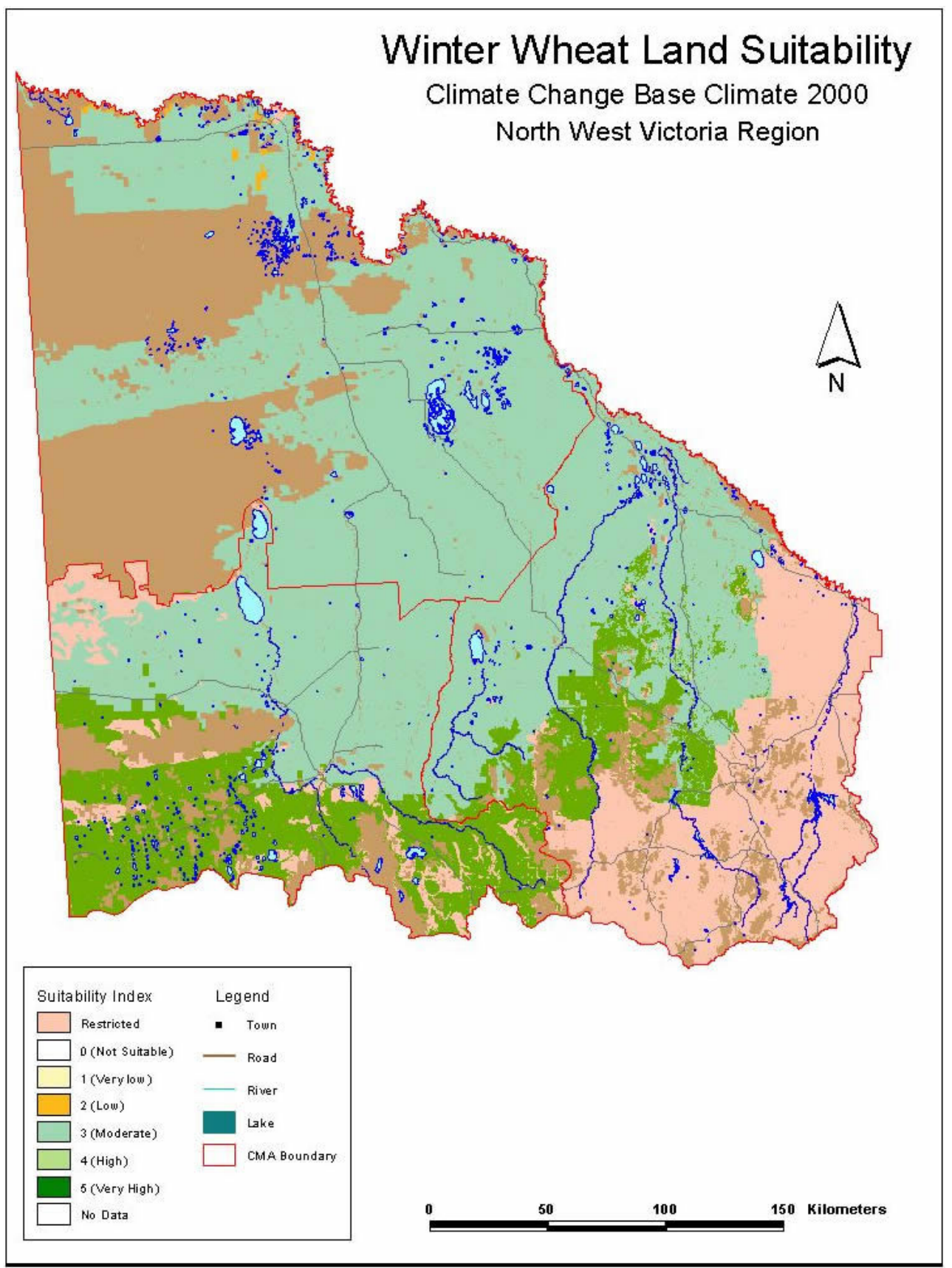

Map 5 Winter Wheat Land Suitability - Baseline Year 2000 


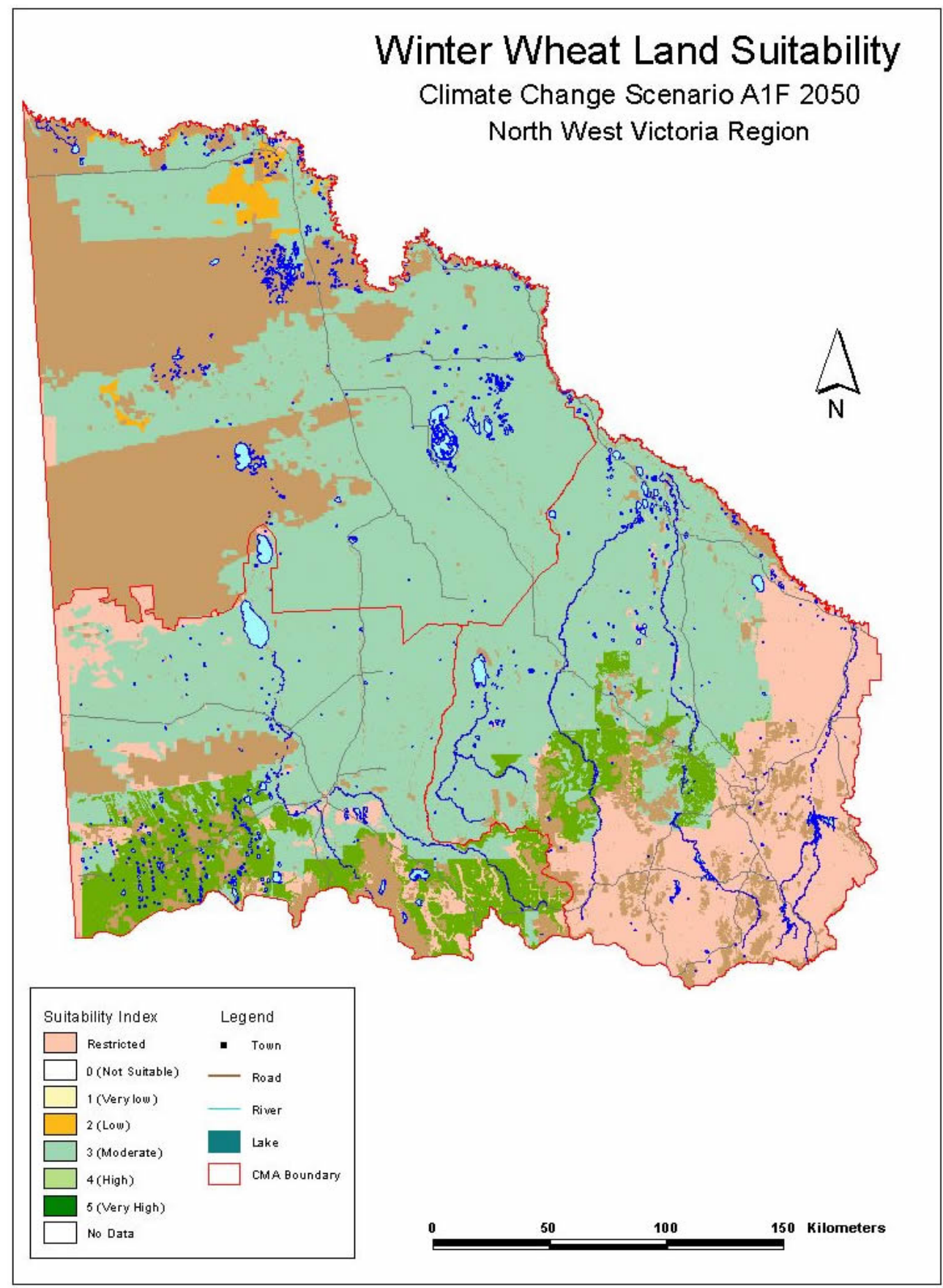

Map 6 Winter Wheat Land Suitability - Extreme Emissions Scenario A1F1 - 2050 


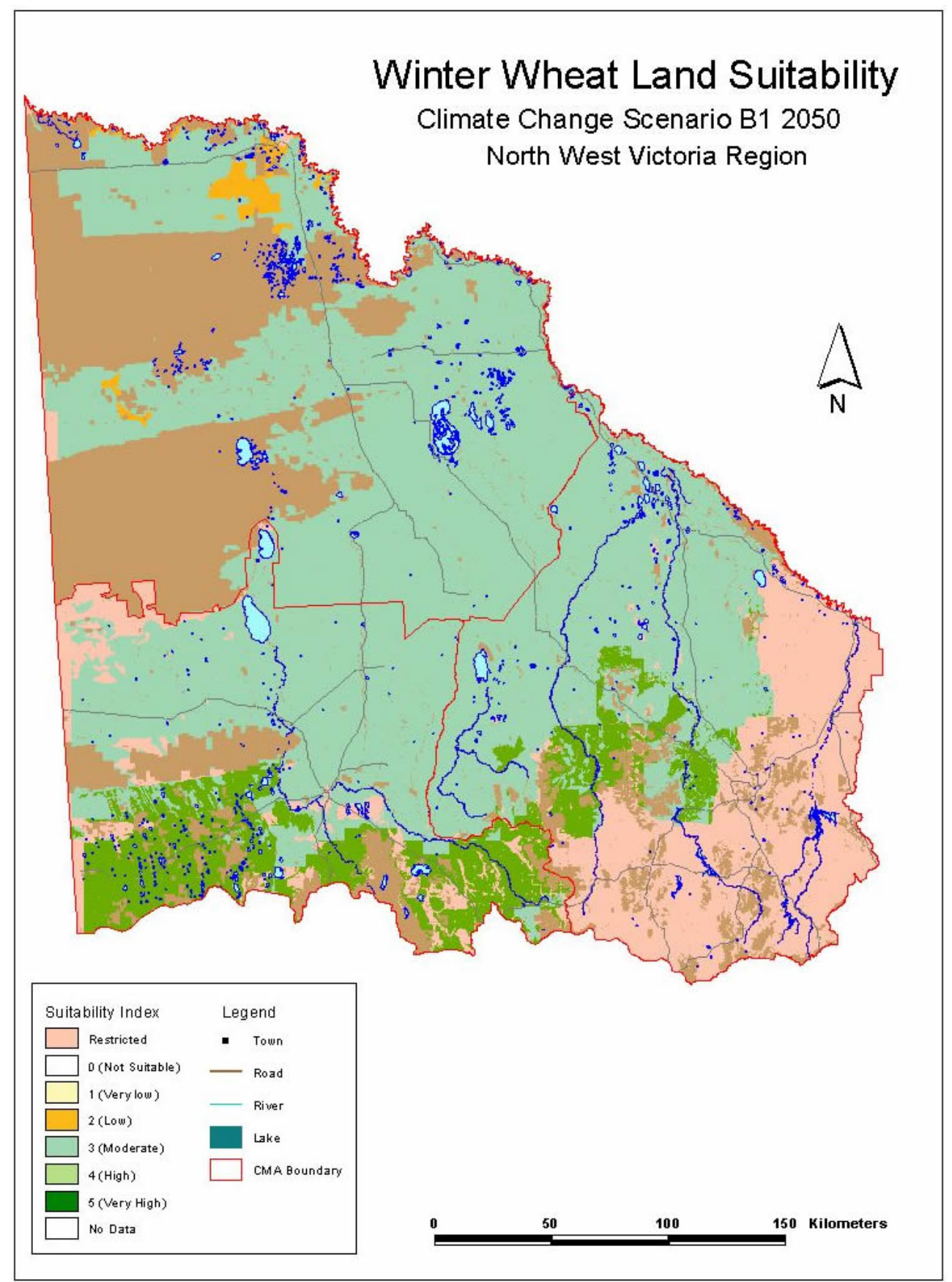

Map 7 Winter Wheat Land Suitability - Moderate Emissions Scenario B1 - 2050 


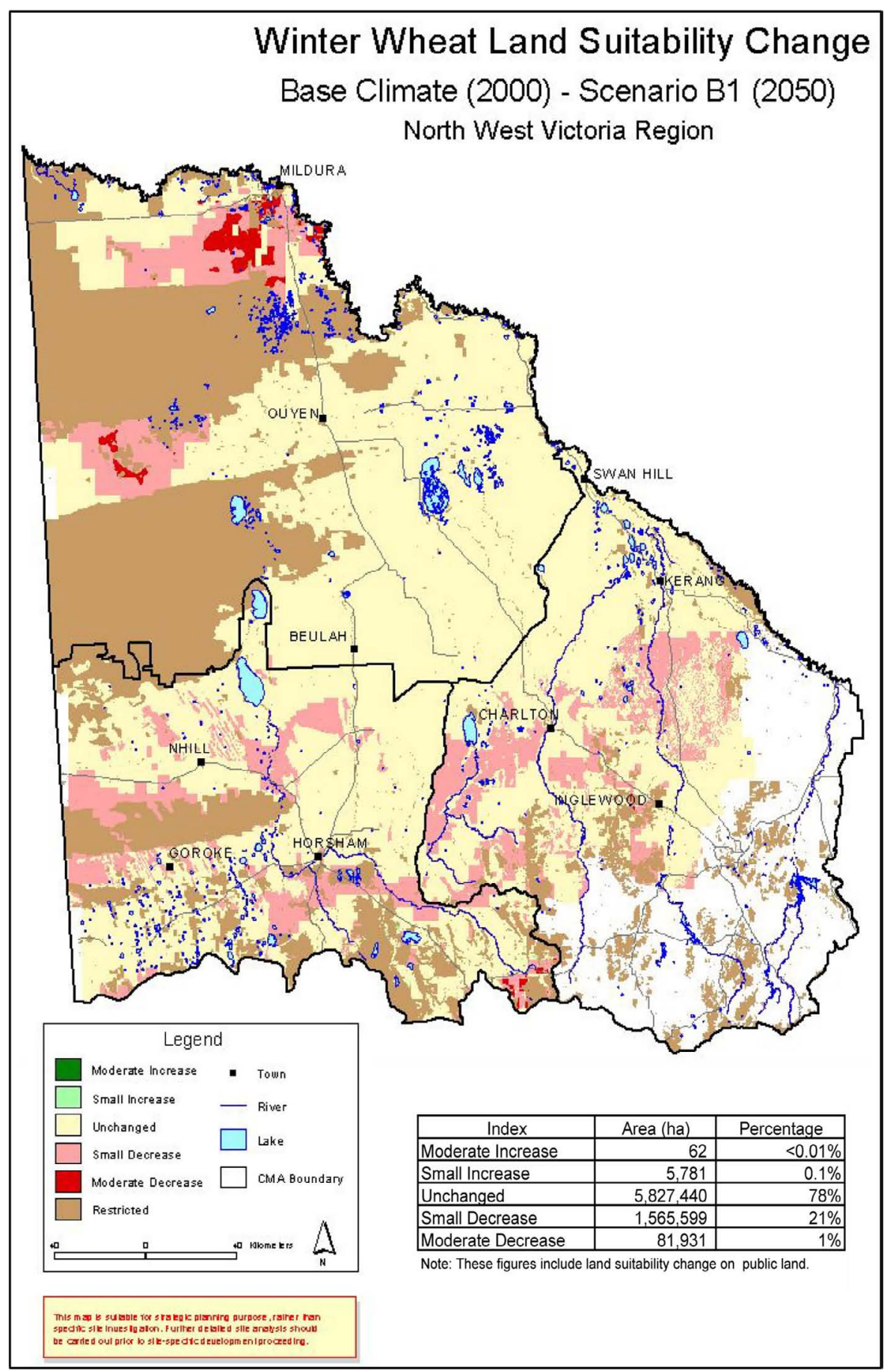

Map 8 Winter Wheat Land Suitability (B1 - 2050) - Comparison between Baseline Climate (2000) and Moderate Scenario 


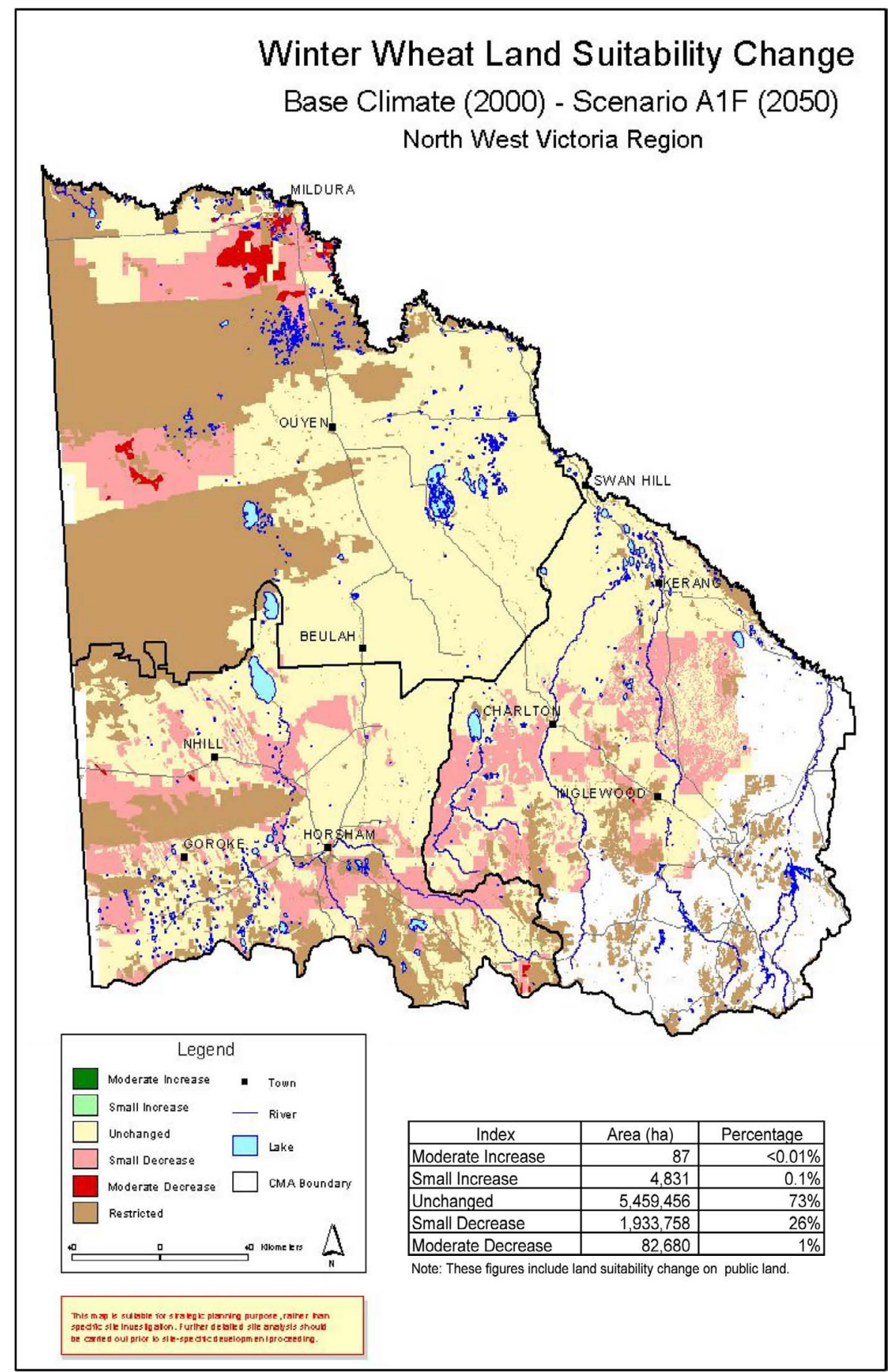

Map 9 Winter Wheat Land Suitability (A1F1 - 2050) - Comparison between Baseline Climate (2000) and Extreme Scenario 


\section{CONCLUSIONS}

The main conclusions reached in the research described above are summarised below; they are categorised in (a) methodological lessons, (b) application pointers, and (c) further research.

\section{METHODOLOGICAL LESSONS}

1. Land suitability analysis models and climate change impact models can be integrated successfully. This integration enhances the capability of both modelling approaches for exploring the biophysical impacts of human-induced climate change on natural resource-based industries and land use.

2. The model integration is appropriate for providing a long-term perspective at a regional scale. The approach (a) is well suited to model average climate conditions, (b) expresses well spatial variation in climate change scenarios, and (c) provides sound starting points (broadscale) for climate change risk assessment.

3. Seasonal impacts would be however a major determinant of an agricultural system resilient and its productivity (Brown and Rosenberg 1999; Howden 2003). It is therefore important to link climate change long-term projections (scenarios) with climate variability (seasonal) forecasting. The initial results from a PIRVic research addressing these issues are reported in Anwar et al (2006).

\section{APPLICATION POINTERS}

1. The potential impacts of climate change have complex spatial implications. They would vary across regions and industries for different aspects of climate change and at a range of geographic scales. Rather than simply modify its size, areas of suitability for specific agricultural commodities may also move in their geographical location.

- At the intra-regional level, for instance, the maps of climate change scenarios for apple production in the Goulburn Broken Region of the State of Victoria (Maps 2-4) show that the area which is highly suitable for growing apples may expand in size as well as migrate towards the south-west of the region. Similar changes in land suitability can be discerned in the sequence of maps for Winter Wheat in the North-Western Region of Victoria (Maps 5-7).

- At the inter-regional level, for example, current pome fruit varieties would suffer from excess heat accumulation in the Goulburn Broken Region. In contrast, there would not be a significant impact on blue gums in the Gippsland Region of Victoria. Parallel studies demonstrate that this variability also applies to other natural resource-based industries (such as fisheries) and natural phenomena (such as biodiversity).

- This changing pattern of suitability would have major implications for the provision of public and private services, including water, fixed infrastructure and energy. It would also have significant implications for the life of rural towns. For some farmers, and regional/rural industries based on their products, 
climate change would mean a reduction in the traditional, historic production of some agricultural commodities, but for others, it would open up new opportunities.

2. The pathway to adapting to climate change is likely to be a series of shorter-term actions moving towards long-term strategic goals. Short-term activities, such as crop choice in agriculture, can be useful adaptation options that are implemented incrementally, so they can respond to climate variability on a seasonal basis. On the other hand, the impact of agricultural activities on landscape systems and its effects on processes, such as salinisation, will require long-term planning horizons to be exercised.

\section{FURTHER RESEARCH}

1. Treatment and communication of uncertainty: Uncertainties dominate climate change assessments; they propagate throughout the chain of models (see Figure 3 and Endnote 5). They can be distinguished according to those that may be reduced with improved knowledge, and those that remain due to fundamental system uncertainty. Estimation of uncertainty of future climate and/or its impacts requires examining the results of all possible combinations of assumptions, which may number in the thousands. Estimation of these uncertainties may require the introduction of 'Bayesian statistics', but scientists and policy makers have only started to come to grips with this complex problem (Pittock 2005). Nevertheless, even if changes in climate could be accurately predicted, uncertainty would still surround the effects that these changes will have in our society and economic activities.

2. Climate change impacts on water - waterways and groundwater systems: These impacts are very complex and only recently being holistically studied; in Australia, a dry continent, they would have major consequences (State of the Environment Advisory Council 1996; Pittock 2003; The State of Victoria 2006). Climate change impacts on water should hence be incorporated into the main environmental models (suitability and crop yields) used in the Framework (Stage 3 in the Framework - Figure 2).

3. Climate change impacts on endemic and exotic pests and pathogens: Climate change would influence the distribution and biology of pests and pathogens, which, in turn, would have major impacts on plant health and production. These potential effects are not clearly understood yet (Aurambout et al. 2006).

4. Visualisation: Three-dimensional (3-D) and four-dimensional (4-D) visualisation tools could be used to envision alternative landscape futures based on climate change and variability models and engage better with stakeholders; see Pettit, et al. (2006) in this special issue of Applied GIS.

5. Decision Support System: The Framework ought to be further developed as a Decision Support System - interactive, integrative, flexible and user-friendly system that includes a dedicated set of tools supporting decision-making process across different scales and contexts (see Sposito et al. 2006b in this special issue of Applied GIS). 


\section{CLOSING REMARKS}

Extensive scientific evidence shows that human-induced climate change is already happening. "Projected climate change will have beneficial and adverse environmental and socio-economic effects, but the larger the changes and rate of change in climate, the more adverse effect predominates" (IPCC 2001a: 67). Therefore, humankind is confronted with major climate impacts on numerous Earth's systems, affecting in turn its survival. We should remember that an estimated change of only about $5^{\circ} \mathrm{C}$ over 10,000 years most likely provoked the extinction of dinosaurs. The same magnitude of change in temperature is now facing us, but in a period of only 100 years.

Mitigation and adaptation are complementary strategies but largely operate on different geographic scales, whereas the primary benefits of adaptation are generally local and regional, mitigation will reduce climate change at the global scale. However successful we are in reducing greenhouse gas emissions, we will still need to adapt and cope with its impacts. Natural resource and spatial planners and decision-makers working at national, state/regional and local levels should then have a primary role in confronting the challenge of climate change. The author believes that the analysis presented in this paper should be an integral part in the formulation of regional and local sustainable development strategies, policies and plans.

\section{ACKNOWLEDGEMENTS}

This paper is based on research in climate change conducted by PIRVic in collaboration with CSIRO Atmospheric and Marine Research - Climate Impact Group. Drs. Penny Whetton, Kevin Hennessy, Cher Page and Bob Cechet (CSIRO) were significant contributors to the research and some of its reports (Sposito et al. 2004; Hood et al. 2002).

Particular thanks are extended to the Australian Greenhouse Office (AGO), the Greenhouse Policy Unit of the Victorian Department of Sustainability and Environment, and the Agriculture Development and Strategic Policy Divisions of the Victorian Department of Primary Industries for funding the research. 


\section{ENDNOTES}

Climate change refers to any change in climate over time, whether due to natural variability or as result of human activity. Climate variability refers to variations in the mean state and other statistics (e.g.; standard deviations, the occurrence of extremes) of the climate on all temporal and spatial scales beyond that of weather events (Pittock 2003).

GHG include carbon dioxide $\left(\mathrm{CO}_{2}\right)$, methane $(\mathrm{CH} 4)$, nitrous oxide $(\mathrm{N} 2 \mathrm{O})$ and ozone, and chlorofluorocarbons (CFCs), and water vapour. The amount of water vapour generated depends on surface temperature, thus providing a reinforcing or positive feedback effect.

The complexity and uncertainty associated with climate change issues suggest that problem understanding can only come from creating possible solutions and considering how they might work. In this sense, climate change can be considered as a "wicked problem". The scientist who coined this term, Horst Rittel, advanced that wicked problems are distinguished by the following characteristics (Rittel 1972): (i) A problem is not fully understood until a solution has been developed; (ii) wicked problems have no stopping rule; (iii) solutions to wicked problems are not right or wrong, (iv) every wicked problem is essentially unique and novel; (v) every solution to a wicked problem is a 'one-shot operation'. Thus, it is a matter of creativity to devise potential solutions, and a matter of judgement to determine which are valid, which should be pursued and implemented (Conklin 2005). The methodological approach for the project described in this paper benefited from this insight by been rooted in both creativity and judgement (including that of stakeholders).

Framework in this paper refers to a combination of (i) approach that prescribes an entire process of assessment and which may include a certain (ii) method or methods (sequence of actions designed to achieve a specified result) which in turn may employ various (iii) tools or instruments or means by which a specific task is accomplished.

This fairly linear approach results in the propagation of uncertainty throughout the process of climate change projections and impact assessment. This has been variously described as a "cascade of uncertainty" (Schneider 1983; Jones 2000) or as or the "uncertainty explosion" (Henderson-Sellers 1993). It is therefore incumbent on a climate change impact/risk assessment to minimise unquantified uncertainty by utilising a wide range of possible futures (i.e. scenarios). Estimation of uncertainty of future climate and/or its impacts requires looking at the results of all possible combinations of thousands of assumptions (Pittock 2005). This requires complex calculations; it is known as 'Bayesian statistics'. An application of the Bayesian approach can be seen in the paper by McNeill et al. (2006) in this special issue of Applied GIS.

\section{REFERENCES}

Alcamo, J. 2002. 'Introduction to the Special Issue on Regional Air Pollution and Climate Change in Europe'. Environmental Science and Policy 5: 255.

Anwar, M.; O’Leary, G.; McNeill, D.; Hossain, H.; Nelson, R. 2006. 'Climate change impact on field crops and adaptation options in Southeastern Australia'. International Conference of the Australian Society of Agronomy. September 2006.

Aurambout, J-P.; Constable, F.; Luck, J.; Sposito, V. 2006. 'The Impacts of Climate Change on Plant Biosecurity - Literature Review'. Melbourne: Department of Primary Industries and Cooperative Research Centre for Plant Biosecurity.

Australian Greenhouse Office. 1998. National Greenhouse Office: Strategic Framework for Advancing Australia's Greenhouse Response. Canberra: Commonwealth of Australia.

Beder, S. 1996. The Nature of Sustainable Development. Sydney: Scribe Publications. 
Brown, R; Rosenberg, N. 1999. 'Climate change impacts on the potential productivity of corn and winter wheat in their primary United States growing regions'. Climatic Change 41: 73-107.

Burgman, M. 2005. Risks and Decisions for Conservation and Environmental Management, Cambridge: Cambridge University Press.

Carver, S. 1991. 'Integrating multi-criteria evaluation with geographical information systems'. International Journal of Geographical Information Systems 5 (3): 321-339.

Centre for Integrated Regional Assessment (CIRA). 2004. 'The CIRA Framework for Integrated Regional Assessment'. Available from: http://www.cira.psu.edu/framework.htm.

Collins, D; Della-Marta, P; Plummer, N; Trewin, B. 2000. 'Trends in annual frequencies of extreme temperature events'. Australian Meteorological Magazine 49: 277-292.

Conklin, J. 2005. Dialogue Mapping: Building Share Understanding of Wicked Problems, Wiley - See also http://cognexus.org.

CSIRO - Commonwealth Scientific and Industrial Research Organisation. 2001. Climate Change - Projections for Australia, CSIRO Atmospheric Research: Melbourne.

Curran, M. et al. 2003. 'Ice Core Evidence of Antarctic Sea Ice Decline since the 1950s'. Science 302: 1203-1206; cited in Flannery, 2005: 97.

Department of Primary Industries. 2006. 'DPI Action Agenda on Climate Change Adaptation and Greenhouse - Growing Sustainable Primary Industries’. Melbourne: Department of Primary Industries.

Department of the Environment and Heritage, Australian Greenhouse Office - AGO. 2005. 'Climate Change Risk and Vulnerability', prepared by the Allen Consulting Group. Canberra: AGO.

Diamond, J. 2005. Collapse - How Societies Choose to Fail or Survive. Melbourne: Allen Lane and imprint of Penguin Books.

Feenstra, J.; Burton, I.; Smith, J.;Tol, R. (eds). 1998. Handbook on Methods for Climate Change Impact Assessment and Adaptation Strategies, Nairobi (Kenya) and Amsterdam (The Netherlands): United Nations Environment Programme and Institute for Environmental Studies.

Flannery, T. 2005. The Weather Makers -The History and Future Impacts of Climate Change. Melbourne: The Text Publishing Company.

Henderson-Sellers, A. 1993. 'An Antipodean Climate of Uncertainty'. Climatic Change 25: 203-224.

Hood, A.; Hossain, H.; Sposito, V.; Tiller, L.; Cook, S.; Jayawardana, J.; Ryan, S.; Skelton, A.; Cechet, B.; Whetton, P.; Hennessy, K.; Page, C.; Suppiah, R. and Bathols, J. 2002. 'Options for Victorian Agriculture in a "new" Climate - a pilot study linking climate change scenario modelling and land suitability modelling, Phase 1 - Concepts and Analysis'. Melbourne: DNRE.

Hossain, H; Evans, C; Sposito, V. 2006. 'Sustainable land resource assessment in regional and urban systems'. Applied GIS 2 (3). 24.1-24.21. DOI: 10.2104/ag060024.

Howden, M. (ed). 2003. 'An overview of the adaptive capacity of the Australian agricultural sector to climate change - options, costs and benefits'. Canberra: CSIRO Sustainable Ecosystems.

IAWG. 2001. Climate Change Impacts for Australia, Aitkenvale, Queensland: CSIRO Impacts and Adaptation Working Group (IAWG).

Intergovernmental Panel on Climate Change - IPCC. 1994. IPCC Technical Guidelines for Assessing Climate Change Impacts and Adaptations. London: Department of Geography, University College.

IPCC. 1995. Impacts, Adaptations and Mitigation of Climate Change: Scientific-Technical Analyses, Contribution of Working Group II to the Second Assessment Report of the Intergovernmental Panel on Climate Change (IPCC). Watson, R.; Zinyowera, M. and Moss, R. (eds). Cambridge: Cambridge University Press.

IPCC. 2001a. Climate Change 2001: Synthesis Report - A Contribution of Working Groups I, II, and III to the Third Assessment Report of the Intergovernmental Panel on Climate Change. Cambridge: Cambridge University Press.

IPCC. 2001b. Climate Change 2001: The Scientific Basis, Contribution of Working Group I to the Third Assessment Report (TAR) on the Intergovernmental Panel on Climate Change (IPCC), Houghton, 
J.; Ding, Y.; Griggs, D.; Noguer, P.; van der Linden, P.; Dai, X.; Maskell, K. and Johnson, C. (eds). Cambridge: Cambridge University Press:

IPCC. 2001c. Climate Change 2001: Impacts, Adaptation and Vulnerability, Contribution of Working Group II to the Third Assessment Report (TAR) of the Intergovernmental Panel on Climate Change (IPCC). McCarthy, J.; Canziani, O.; Leary, N.; Dokken, D. and White, K. (eds). Cambridge: Cambridge University Press.

IPCC. 2001d. Climate Change Impacts, Adaptation and Vulnerability - Summary for Policy Makers, Intergovernmental Panel on Climate Change (IPCC). Cambridge: Cambridge University Press.

Jankowski, P. 1995. 'Integrating geographical information systems and multiple criteria decision-making'. International Journal of Geographical Information Systems 9 (3): 251-273.

Jones, R. 2000. 'Managing uncertainty in climate change projections - issues for impact assessment, An Editorial Comment'. Climatic Change 45: 403 - 419.

Jones, R. 2001. 'An environmental risk assessment/management framework for climate change impact assessment'. Natural Hazards 23: 197-230.

Jones, R. 2003. Managing Climate Change Risks, Working Paper, Working Party on Global and Structural Policies. Paris: OECD.

Kenney, R.; Raiffa, H. 1993. Decision with Multiple Objectives: Preferences and Value Trade-offs. Cambridge: Cambridge University Press.

McNeill, J; MacEwan, R; Crawford, D. 2006. 'Using GIS and a land use impact model to assess risk of soil erosion in West Gippsland'. Applied GIS 2 (3): 19.1-19.17. DOI: 10.2104/ag060019.

Metzger. M. 2005. European vulnerability to global change - spatially explicit and quantitative assessment, $\mathrm{Ph}$. D. Thesis Wageningen University: Wageningen, The Netherlands.

Metzger, M.; Leemans, R.; Schroter, D.; Cramer, W. and the ATEAM Consortium. 2004. 'The AEAM vulnerability mapping tool'. Quantitative Approaches in Systems Analysis 27, University of Wageningen: The Netherlands.

Nakicenovic, M.; Swart, R. (editors) 2000. IPCC Special Report on Emissions Scenarios (SRES). Cambridge: Cambridge University Press.

Nijkamp, P. et al. 1990. Multicriteria Evaluation in Physical Planning. Amsterdam: North Holland.

Parry, M.; Carter, T. 1998. Climate Change Impact and Adaptation Assessment: A Guide to the IPCC Approach. London: Earthscan Publications.

Pearman, G. 2005. 'Climate Change and Sustainability'. BDP Environment Design Guide, GEN 68, August 2005. Melbourne: RAIA.

Pettit, C; Cartwright, W; Berry, M. 2007. 'Geographical visualisation: A participatory planning support tool for imagining landscape futures'. Applied GIS 2 (3): 22.1-22.17. DOI: 10.2104/ag060022.

Pittock, B. (editor) 2003. Climate Change: An Australian Guide to the Science and Potential Impacts. Australian Greenhouse Office: Canberra.

Pittock, B., 2005. Climate Change - Turning Up the Heat. Melbourne: Earthscan, CSIRO Publishing.

Ramanathan, R. 2001. 'A note on the use of the analytic hierarchy process for environmental impact assessment'. Journal of Environmental Management 63: 27-35.

Reid, W.; Mooney, H.; Cropper, A.; Capistrano, D. et al. 2005. Ecosystems and Human Well-BeingSynthesis, A Report to the Millennium Ecosystem Assessment. Washington DC.: Island Press.

Rittel, H. 1972. 'Structure and Usefulness of Planning Information Systems', No. 108. The Institute of Urban and Regional Development University of California: Berkeley.

Ruosteenoja, K.; Carter, T.; Tuomenvirta, J. 2003. Future climate in world regions: an intercomparison of model-based projections for the new IPCC emission scenarios, The Finish Environment 644, Finish Environment Institute: Helsinki, Finland.

Saaty, T. 1994. Fundamentals of Decision Making with the Analytic Hierarchy Process. Pittsburgh: RWS Publications.

Saaty, T.1995. Decision Making for Leaders. Pittsburgh: RWS Publications. 
Saaty, T.; Vargas, L. 2001. Models, Methods, Concepts \& Applications of the Analytic Hierarchy Process. Norwell: Kluwer Academic Publishers.

Schmold, D.; Kangas, J.; Mendoza, G.; Pesonen, M. 2001. The Analytic Hierarchy Process in Natural Resource and Environmental Decision Making. Dordrecht: Kluwer Academic Publishers.

Schneider, S.H. 1983. ' $\mathrm{CO}_{2}$, Climate and Society: A Brief Overview'. Edited by Chen, R. S.; Boulding, E.; Schneider, S. H. Social Science Research and Climate Change: An Interdisciplinary Appraisal. D. Reidel: 9-15: Boston.

Schroter, D.; Acosta-Michlik, L.; Arnell, A.; Araujo, M. et al. 2004. The ATEAM Final report 2004 -Section 5 and 6 and Annex 1 to 6 - Detailed report related to the overall project duration, Potsdam Institute for Climate Impact Research, Potsdam: Germany. www.pik-potsdam.de/ateam/.

Sietchiping, R. 2006. 'An Adaptive Capacity Index to Climate Change: Communities in the Grains Industry of Northwest Victoria, Australia'. Applied GIS, December 2006.

Sposito, V.; Evans, C.; Fitzsimons, P. and Hossain, H. 2006a. 'Adaptation to Climate Change and Adaptive Capacity in Agricultural Systems - Literature Review'. Melbourne: Department of Primary Industries (DPI).

Sposito, V; Wyatt, R; Pettit, C. 2006b. 'Strategic thinking for improved regional planning and natural resources management' [Editorial]. Applied GIS 2 (3): 15.1-15.7. DOI: 10.2104/ag060015.

Sposito, V.; Hossain, H.; Watson, D. and Barnes, D. 2005. 'Climate Change Adaptation in Victoria: Agricultural Risk Assessment'. Melbourne: Department of Primary Industries (DPI).

Sposito, V.; Hossain, H.; Watson, D. and Gyaw, S. 2004. 'Options for Victorian Agriculture in a "new" Climate - a pilot study linking climate change scenario modelling and land suitability modelling, Phase 2 - Impacts and Adaptation'. Melbourne: Department of Primary Industries (DPI).

State of the Environment Advisory Council - SOEAC. 1996. Australia - State of the Environment 1996. Melbourne: CSIRO Publishing.

Standards Australia/Standards New Zealand. 2004. Risk Management - AS/NZS 4360:2004. Sydney: Standards Australia International and Standards New Zealand.

Steffen, W.; Sanderson, A.; Tyson, P.; Jager, J. et al. 2004. Global Change and the Earth System - A Planet under Pressure. Springer.

The State of Victoria, Department of Sustainability and Environment - DSE. 2004. Adapting to Climate, Enhancing Victoria's Capacity - Consultation Paper. Melbourne: DSE.

The State of Victoria, Department of Sustainability and Environment - DSE. 2005. Victorian Greenhouse Strategy Action Plan Update. Melbourne: DSE.

The State of Victoria, Department of Sustainability and Environment - DSE. 2006. Our Environment Our Future - Sustainability Action Statement. Melbourne: DSE.

The State of Victoria, Department of Natural Resources and Environment - DNRE. 2002. Victorian Greenhouse Strategy. Melbourne; DNRE.

Turner, B; Kasperson, R; Matson, P; McCarthy, J. 'A framework for vulnerability analysis in sustainability science'. Proceedings of the National Academy of Sciences USA. 100 (14): 8074-8079.

United Nations Development Program - UNEP. 2001. Adaptation Policy Framework. Available from: http://www.undp.org/cc/apf_outline.htm. 
Voogd, H. 1983. Multicriteria Evaluation for Urban and Regional Planning. London: Pion.

Whetton, P.; Suppiah, R.; McInnes, K.; Hennessy, K. and Jones, R. 2002. Climate Change in Victoria: high resolution regional assessment of climate change impacts. Melbourne: Department of Natural Resources and Environment (DNRE).

Willows, R.; Connell, R. (eds). 2003. Climate adaptation: Risk, uncertainty and decision-making. UKCIP: UKCIP Technical Report. Oxford.

World Commission on the Environment and Development - WCED. 1987. Our Common Future. Cambridge: Cambridge University Press.

Cite this article as: Sposito, Victor A. 2006. 'A strategic approach to climate change impacts and adaptation'. Applied GIS 2 (3): pp. 23.1-23.26. DOI: 10.2104/ag060023. 